\title{
Acidic solution effects on no-fines concrete produced by using recycled concrete as coarse aggregate
}

\author{
Ikbal Gorgis ${ }^{1 *}$, Whab Faleh Abd ${ }^{1}$ and Shaker Al-Mishhadani ${ }^{1}$ \\ ${ }^{1}$ Building and Construction Engineering Department, University of Technology, Baghdad, Iraq
}

\begin{abstract}
This paper investigates durability of no fine concrete containing demolished concrete as coarse aggregate after crushing to different sizes. Different no fine concrete mixes were considered using Portland cement type I with two types of coarse aggregates, crushed demolished concrete and crushed natural gravel were used with two ratios by weight (1:5 and 1:7) C/Agg. Graded aggregate and single size were used with a maximum size of $20 \mathrm{~mm}$. W /C ratio was kept as 0.4 for all mixes and super-plasticizer was required to keep the same flow and compaction factor value for all mixes. Cube specimens with $150 \mathrm{~mm}$ were cured and divided to two parts, the first part was exposed to 60 cycles of freezing- thawing; the second part of the sample was immersed in Nitric Acids solution with $\mathrm{pH}$ of 3.5 for (7, 28, 90 and 180 days) and then tested for compressive strength. The results indicated that it is possible to produce homogenous and workable mixes by using demolished crushed concrete as coarse aggregate. The compressive strength after cycles of freezing- thawing and immersing in Nitric acid (HNO3) at (7, 28, 90 and 180) days was decreased for samples made with crushed demolished concrete. Also it is found that the performance of concrete mixes containing graded coarse aggregate and 1:5 cement/aggregate ratios was better than other mixes.
\end{abstract}

\section{Introduction}

No fine concrete is a method of producing lightweight concrete by removing the sand from conventional concrete. This concrete is consisting of only cement, coarse aggregate and water [1]. Very often only grading and single sized coarse aggregate of size passing through sieve $(20 \mathrm{~mm})$ retained on sieve $(10 \mathrm{~mm})$ is used. Because of some of the advantages it possesses over the conventional concrete, no fines concrete is becoming popular.

Safeguarding of natural resources, recycling of waste materials and the protecting the environment have become of paramount importance. To reduce the problem of cumulative waste, dumping should be used in an environmentally safe method either as economical and beneficial purposes or as raw materials for other products. Lightweight concrete has become commonly used recently because of huge development in the construction techniques and methods of mixing. Moreover, the use of demolished concrete for the purpose of manufacture of lightweight concrete can represent the double benefits of using this waste, thus cleaning the environment, and also by the production of good concrete which can be used [2]. Durability of concrete may be defined as the ability of concrete to resist weathering action, chemical attack and abrasion while maintaining its desired engineering properties.

Wen et al [3] showed the effect of using waste concrete as coarse aggregate in new concrete pavements.

\footnotetext{
* Corresponding author: iqbalkorkess@yahoo.com
}

Variables included the source of the recycled coarse aggregate (RCA) percent replacement of coarse natural aggregate with waste concrete as aggregate ( $0 \%$ to $45 \%)$. Replacement of rubble concrete as aggregate for natural coarse aggregate by up to $(45 \%)$ by volume had no significant effect on any of the concrete properties. These results indicate that high quality waste concrete as aggregate can be used as a replacement for a portion of the coarse natural aggregates in new Portland cement concrete pavements.

Witchayangkoon et al [4] showed the effect of using waste concrete as a replacement of natural coarse aggregate to produce concrete paving blocks. The experiment was conducted to monitor concrete strength of the specimen samples. Waste concrete as aggregate has been used in different proportions $(50 \%, 70 \%$, and $100 \%$ ) as replacement of natural coarse aggregate. The mix concrete uses $\mathrm{W} / \mathrm{C}$ ratio of (0.47) with design slump $(100 \pm 25) \mathrm{mm}$. Average concrete strengths at 28 days were $(66.5,45.6$ and 35.0) MPa. Thus, this work showed possibility that dumped concrete could be recycled with full $(100 \%)$ replacement of coarse aggregate in making concrete paving blocks.

Qasrawi et al [5] studied the effect of using rubble concrete as aggregates on the basic properties of normal concrete. Results showed that the use of demolished concrete as recycled aggregates has an adverse effect on the workability of concrete. Such an effect can be easily retained by using plasticizers. The ratio of aggregate replacement used was $(25,50,75$ and $100 \%)$ by weight 
of coarse aggregate and water/cement ratio $(0.45,0.55$ and 0.65$)$. Concrete strength has been reduced by ( $5 \%$ to $25 \%$ ) depending on the percent of the normal aggregate replaced by waste concrete as recycled aggregate and the W/C ratio. With respect to the split tensile strength, recycled concrete as aggregate was slightly lower. For example, the use of $(100 \%)$ replacement reduced the compressive strength of the mixes by $(25 \%)$ for W/C ratio $(0.45)$, while in the case of tensile strength this value was $(14 \%)$.

The aims of this research was producing no fine concrete by using demolished concrete as recycled coarse aggregate and comparing the durability of this concrete with no fine concrete produced by using natural aggregate. It was aimed to use local material to maintain the economic side thus, providing an incentive and encouraging using no fine concrete in practical applications as road pavement.

\section{Experimental works}

Materials used to complete the experimental work were:

\subsection{Cement}

Ordinary Portland cement type (I) manufactured in Iraq with a commercial name of (Karasta) was used for no fine concrete mixes throughout the present work. The physical properties and chemical analysis for cement are present in Tables $1 \& 2$. Results showed that the cement conformed to the Iraqi Standard Specification IQS No.5/1984[6].

\subsection{Coarse Aggregate}

Two types of coarse aggregates were used in this study to produce no fine concrete, they were:-

- Natural Crushed Coarse Aggregate: Natural crushed coarse aggregate of $(20 \mathrm{~mm})$ single and grading size, brought from (Al-Soddor source) region. The grading and properties of natural crushed coarse aggregate stratify the Iraqi specification IQS No.45/1980[7], as shown in Tables $3 \& 4$.

- Demolished Concrete Aggregate: A rubble concrete was used as coarse aggregate. It was brought from waste found in the university laboratories (chosen carefully to contain no fiber or lightweight aggregate) and used as $100 \%$ replacement of coarse aggregate. The waste concrete was crushed into smaller sizes manually by a hammer to obtain the required sizes. The grading and properties of demolished concrete as coarse aggregate conform to the Iraqi specification IQS No.45/1980[7], as shown in Table 3 and Table 4. The aggregate grading and single size were similar to that of natural aggregate used in this study.

\subsection{Water}

Ordinary tap water was used for mixing and curing.

\subsection{Admixture}

The superplasticizer used in this work to keep constant $\mathrm{W} / \mathrm{C}$ ratio for all mixes; commercially known as
(Glenium 54), Table 5 shows the typical properties of it. This admixture was identical to the requirement of the ASTM C494-03(8) type F.

Table 1. Chemical composition and main compounds of the cement

\begin{tabular}{|l|l|l|}
\hline Oxide & $\begin{array}{l}\text { Content } \\
\%\end{array}$ & $\begin{array}{l}\text { Limits of Iraqi Specification } \\
\text { No.5/1986[6]. }\end{array}$ \\
\hline $\mathrm{CaO}$ & 66.11 & - \\
\hline $\mathrm{SiO}_{2}$ & 21.93 & - \\
\hline $\mathrm{Al}_{2} \mathrm{O}_{3}$ & 4.98 & - \\
\hline $\mathrm{Fe}_{2} \mathrm{O}_{3}$ & 3.10 & - \\
\hline $\mathrm{MgO}$ & 2.0 & $<5$ \\
\hline $\mathrm{SO}_{3}$ & 2.25 & $<2.8$ \\
\hline Insoluble Residue I.R & 1.29 & $<1.5$ \\
\hline Loss on ignition L.O.I & 2.39 & $<4.0$ \\
\hline $\begin{array}{l}\text { Lime Saturation } \\
\text { Factor, }\end{array}$ & 0.93 & $0.66-1.02$ \\
\hline Main Compounds(Bogue's equations) \\
\hline C3S & 64.57 & - \\
\hline C2S & 14.15 & - \\
\hline C3A & 7.95 & $>3.5$ \\
\hline C4AF & 9.43 & - \\
\hline
\end{tabular}

Table 2. Physical properties of cement.

\begin{tabular}{|l|c|c|}
\hline \multicolumn{1}{|c|}{ Physical properties } & $\begin{array}{c}\text { Test } \\
\text { results }\end{array}$ & $\begin{array}{l}\text { Limit of Iraq } \\
\text { specification ( No. 5- } \\
\text { 1984)[6] }\end{array}$ \\
\hline $\begin{array}{l}\text { Specific surface area } \\
\text { (Blaine method), } \mathrm{m}^{2} / \mathrm{kg}\end{array}$ & 376 & $\geq 230$ \\
\hline $\begin{array}{l}\text { Setting time (Vicate } \\
\text { apparatus), }\end{array}$ & $1: 05$ & $\geq 45 \mathrm{~min}$. \\
$\begin{array}{l}\text { Initial setting time, hrs: } \\
\text { min }\end{array}$ & $4: 00$ & $\leq 10 \mathrm{hrs}$ \\
$\begin{array}{l}\text { Final setting time, hrs: } \\
\text { min }\end{array}$ & & \\
\hline $\begin{array}{l}\text { Soundness (Autoclave ) } \\
\text { method, \% }\end{array}$ & 0.12 & $\leq 0.8$ \\
\hline
\end{tabular}

Table 3. Grading and physical properties of single size coarse aggregate

\begin{tabular}{|c|c|c|c|}
\hline No & $\begin{array}{c}\text { Sieve size } \\
(\mathrm{mm})\end{array}$ & \multicolumn{2}{|c|}{ Percentage passing } \\
\hline & & $\begin{array}{l}\% \\
\text { Passing }\end{array}$ & $\begin{array}{l}\text { (Limits of Iraqi specification } \\
\text { No.45/1980)[7] }\end{array}$ \\
\hline 1 & 20 & 100 & $85-100$ \\
\hline 2 & 10 & 14 & $0-25$ \\
\hline 3 & 5 & 1 & $0-5$ \\
\hline 4 & 2.36 & - & - \\
\hline Sulfate content (\%) & 0.08 & $\leq 0.1 \%$ \\
\hline Specific gravity & 2.69 & \\
\hline \multicolumn{2}{|l}{ Absorption (\%) } & 0.55 & \\
\hline
\end{tabular}

Table 4. Grading and physical properties of coarse aggregate.

\begin{tabular}{|l|c|c|c|c|}
\hline No. & \begin{tabular}{l} 
Sieve size \\
\multirow{2}{*}{}
\end{tabular} & & \multicolumn{3}{|c|}{ Percent passing \% } \\
\cline { 2 - 5 } & $\begin{array}{l}\text { Natural } \\
\text { aggregat } \\
\mathrm{e}\end{array}$ & $\begin{array}{l}\text { Demolished } \\
\text { aggregate }\end{array}$ & $\begin{array}{l}\text { Limits of Iraqi } \\
\text { Specification No. } \\
45 / 1980(7)\end{array}$ \\
\hline 1 & 20 & 100 & 100 & $85-100$ \\
\hline 2 & 10 & 30 & 30 & $30-60$ \\
\hline 3 & 5 & 0 & 0 & $0-10$ \\
\hline 4 & 2.36 & - & - & - \\
\hline \multicolumn{2}{|l}{ Sulfat content (\%) } & 0.08 & 0.08 & $\leq_{0.1 \%}$ \\
\hline \multicolumn{2}{|l}{ Specific gravity } & 2.69 & 2.48 & \\
\hline \multicolumn{2}{|l}{ Absorption (\%) } & 0.55 & 4.5 & \\
\hline
\end{tabular}


Table 5. Technical description of high range water reducing admixture

\begin{tabular}{|l|c|}
\hline \multicolumn{2}{|c|}{ Technical properties T $25^{\circ} \mathrm{C}$} \\
\hline color & Dark Brown \\
\hline Specific gravity & $1.21 @ 25 \pm 2^{\circ} \mathrm{C}$ \\
\hline Chloride content & Nil \\
\hline Flash point & N/A \\
\hline PH & 6.6 \\
\hline viscosity & $128+/-30 \mathrm{cps} @ 25 \pm 2^{\circ} \mathrm{C}$ \\
\hline
\end{tabular}

\section{Mixing of no fine concrete}

Trail mixes were adopted to check the required properties of no fine concrete with suitable amount of $\mathrm{w} / \mathrm{c}$ ratio and converge on the influence of changing aggregate type on durability of no fine concrete. The details for all mixes used in this search are presented in Table 6. Mixing was done by using $(0.1) \mathrm{m}^{3}$ pan tilting mixer, and then cast in oiled steel molds with $100 \mathrm{~mm}$ side dimension and compacted by simple rod ( 25 blows) to prevent any segregation of the mix. All samples were demoulded and immersed in water tank up to age of test.

\section{Fresh concrete tests}

\subsection{Flow test}

This test was conducted for giving the index of the cohesion of the no-fine concrete produced and to show the extent of their tendency to segregation according ASTM C124 -76(9). The increase in the flowing percentage of concrete gives an indication to its higher consistency.

\subsection{Compacting Factor Test}

Compacting factor test is used according to BS 1881: Part 103: 1993(10). The specimen falls from the initial cone and is captured in a second cone. It is then allowed to fall into a test cylinder.

\subsection{Fresh density}

The measurement of concrete density was carried out according to ASTM C138-01(11) in which the average of three cylinders with $(100 * 200) \mathrm{mm}$ masses was considered to determine the fresh concrete density.

\section{Hardened concrete tests}

Durability of no fine concrete with recycled aggregate was required, for which two properties were investigated freezing - thawing as well as to immersing in Nitric acid $\left(\mathrm{HNO}_{3}\right)$ as a replacement of Acidic rain effect.

\subsection{Compressive strength}

Compressive strength test was executed by British Standard BS 1881 part 116:1983(12) using cubical samples size (100x 100x100) $\mathrm{mm}$ and taking the average result of three samples at $(7,28,90$ and 180) days age for each mix.

Table 6, Constituents of no-fine concrete mixes.

\begin{tabular}{|c|c|c|c|c|c|}
\hline No. & $\begin{array}{l}\text { Mix } \\
\text { description }\end{array}$ & Mix Details & $\begin{array}{l}\text { Mix } \\
\text { proportion } \\
\text { by volume } \\
\text { cement: } \\
\text { aggregate }\end{array}$ & $\mathrm{w} / \mathrm{c}$ & S.P \\
\hline \multirow[b]{2}{*}{1} & NSA5 & $\begin{array}{l}\text { Natural single } \\
\text { size aggregate }\end{array}$ & $1: 5$ & 0.4 & - \\
\hline & RCSA5 & $\begin{array}{l}\text { Recycled } \\
\text { concrete single } \\
\text { size aggregate }\end{array}$ & $1: 5$ & 0.4 & - \\
\hline \multirow[b]{2}{*}{2} & NSA7 & $\begin{array}{l}\text { Natural single } \\
\text { size aggregate }\end{array}$ & $1: 7$ & 0.4 & 0.36 \\
\hline & RCSA7 & $\begin{array}{l}\text { Recycled } \\
\text { concrete single } \\
\text { size aggregate }\end{array}$ & $1: 7$ & 0.4 & 0.36 \\
\hline \multirow[b]{2}{*}{3} & NGA5 & $\begin{array}{l}\text { Natural grading } \\
\text { size aggregate }\end{array}$ & $1: 5$ & 0.4 & - \\
\hline & RCGA5 & $\begin{array}{l}\text { Recycled } \\
\text { concrete } \\
\text { grading } \quad \text { size } \\
\text { aggregate }\end{array}$ & $1: 5$ & 0.4 & \\
\hline \multirow[b]{2}{*}{4} & NGA7 & $\begin{array}{l}\text { Natural grading } \\
\text { size aggregate }\end{array}$ & $1: 7$ & 0.4 & 0.36 \\
\hline & RCGA7 & $\begin{array}{ll}\text { Recycled } & \\
\text { concrete } \\
\text { grading } \quad \text { size } \\
\text { aggregate }\end{array}$ & $1: 7$ & 0.4 & 0.36 \\
\hline
\end{tabular}

\subsection{Freezing - Thawing}

This test method covers the determination of the resistance of concrete specimens to rapidly repeated cycles of freezing- thawing in the laboratory. Freezingand-thawing cycle's according to ASTM C666- 03(13) (Procedure A) was used. The freezing-thawing apparatus consists of a suitable chamber in which the cube specimens may be subjected to the specified freezingand-thawing cycle together with the necessary refrigerating and heating equipment and controls to produce continuously and automatically reproducible cycles within the specified temperature requirements. The specimens were completely surrounded by air during the freezing phase of the cycle and by water during the thawing phase. This test method shall consist of alternately lowering the temperature of the specimens from $4.4^{\circ} \mathrm{C}$ to $-17.8^{\circ} \mathrm{C}$ and raising it from $-17.8^{\circ} \mathrm{C}$ to $4.4^{\circ} \mathrm{C}$ within $2 \mathrm{~h}$. Each specimen was exposed to 60 cycles and then checked for compressive strength.

\section{$5.3 \mathrm{Immersed}$ in nitric acid $\left(\mathrm{HNO}_{3}\right)$}

Acidic rain is one of the factors which cause deterioration of concrete. Acid rain, or acid deposition, is a broad term that includes any form of precipitation with acidic components, such as sulfuric or nitric acid that fall to the ground from the atmosphere in wet or dry forms. This can include rain, snow, fog, hail or even dust that is acidic. In this study Nitric acid $\left(\mathrm{HNO}_{3}\right)$ with $\mathrm{pH}$ (3.5) was used. All no fine concrete specimens (cube specimens $100 \mathrm{~mm}$ ) were kept in plastic bags sealed until the age of 28 days then put in plastic tank to be immersed in Nitric acid (HNO3) for PH (3.5- 4). The 
concentration of acid was checked every week till the test day.

\section{Test results}

\subsection{Fresh properties (Flow and Compacting Factor)}

The results of the fresh properties of all no fine concrete mixes (flow and compacting factor) are indicated in Table 7. The results showed that it is possible to have a homogeneous mix using demolished concrete as replacement of coarse aggregate with cement/aggregate (C/A) ratios of 1:5 and 1:7 and w/c ratio of 0.4 . Superplasticizer was used for mixes with $\mathrm{C} / \mathrm{A}$ ratio of $1: 7$ to keep the flow and impact factor nearly the same for all no fine concrete mixes.

The results indicated that using demolished concrete as coarse aggregate causes a slight reduction in compaction factor and flow test compared to natural crushed aggregate. This is due to harsh surface of recycle aggregate. The aggregate / cement ratio had a significant effect on the flow test and compaction factor, in which increasing the aggregate/ cement ratio increased both test results. The type of aggregate size (single or graded) of the used aggregate had significant effect on compaction factor and flow test of mixture productive. Using single size aggregate led to a reduction in flow and compaction factor more than grading size.

\subsection{Density Test Results}

The results of the fresh and oven dry density at (1 and 28) days for all no fine concrete mixes were listed in Table 8 . Where fresh density gives an early expectation of all the hardened properties of concrete, which gives an indication whether the mix will satisfy the requirements of no fines concrete to be used as structural or insulation members. Besides, it gives an early solution to overcome any unsatisfactory property. The fresh density ranges between (1680-1950) kg/m3 for all mixes.

Using demolished concrete as coarse aggregate exhibits a reduction in unit weight (fresh and oven dry densities) compared with natural crushed aggregate nofine concrete. This reduction of fresh density attributed to the demolished concrete aggregate which require large amounts of water to get suitable workability which was avoided by using S.P. Hence, the porous nature of recycle concrete aggregate produces mixes with lower density compared with natural crushed coarse aggregate. In addition the harsh nature of the demolished concrete particles required higher water to overcome the friction problem between the particles leading to more voids and lower density. The mixes with cement/aggregate C/A ratio of 1:7 present lower fresh density as compared with $1: 5$.

Table 8 also indicates the result of oven dry density at (1 and 28) days for all no-fine concrete specimens. In no-fine concrete the oven dry density would be more important because the concrete sample contain large amounts of voids and pores that retain water (mixing water + curing water) inside them.

\subsection{Compressive strength test results}

The average compressive strength results at $(7,28,90$ and 180) days age for all no fines concrete mixes are listed in Table 9. The results showed that the compressive strength increased with the age, which is due to the increasing in the hydration process with time. The compressive strength for no fine concrete containing demolished concrete as coarse aggregate was lower than concrete made of natural coarse aggregate. This is due to interfacial transition zone (ITZ) representing the bond between aggregate and paste and is often weaker than either the aggregate or hydrated cement paste. In no fine concrete with natural aggregate, the (ITZ) occurs between aggregate and cement paste only, while in no fine concrete cast with demolished concrete aggregate, there are two different (ITZs) instead of one, an old (ITZs) occurring between the original aggregate and the old mortar and another new (ITZ ) happening between the demolished concrete aggregate and new cement paste. The weakness in rubble concrete aggregate cause a reduction in compressive strength of no fine concrete.

Fig. 1 shows the relationship between $\mathrm{C} / \mathrm{A}$ ratio and compressive strength, which indicates that the compressive strength increases with decreases percentage of coarse $\mathrm{A} / \mathrm{C}$ ratio. The cement content also has a significant role in compressive strength, where concrete mix with high cement content exhibit higher compressive strength than concrete mix with low cement content due to increase cement paste around aggregate particles leads to improve cohesive strength and bond between aggregate particles and cement paste. Gradation size of aggregate effect on compressive strength led to increase in compressive strength compared with single aggregate type.

\subsection{Freezing - Thawing results}

The cube specimens were cured in water for 14 days and then they were subjected to 60 cycles of freezingthawing. Table 10 represented the compressive strength for all no fine concrete specimens before and after being subjected to 60 cycles of freezing- thawing, respectively. The compressive strength decreased with increasing the cycles of freezing- thawing. Due to reduction in rate of hydration during the period of freezing that led to reduction in the compressive strength for no fine concrete specimens, on the other hand freezing process increased micro-cracks in no fine concrete. Specimens cast with demolished concrete as recycled coarse aggregate has more effect on strength as compared with normal coarse aggregate. Due to nature cellular and high absorption for waste concrete as aggregate, therefore. Freezing water in this type of aggregate is more harmful as increases pores volume. Fig. 2-a indicates the relationship between cement/aggregate ratio and 
freezing-thawing. The results indicate that the compressive strength for no fine concrete specimens that subject to freezing- thawing decrease with increase percentage of coarse aggregate/cement ratio.

Table 7. Fresh properties of all no fine concrete mixes

\begin{tabular}{|c|l|c|c|c|c|}
\hline $\begin{array}{c}\text { Set } \\
\text { No. }\end{array}$ & Mix & C/A & $\begin{array}{c}\text { S.P.by } \\
\text { cement } \\
\text { wt. (\%) }\end{array}$ & $\begin{array}{c}\text { Flow } \\
(\%)\end{array}$ & $\begin{array}{c}\text { Compactin } \\
\text { g Factor }\end{array}$ \\
\hline \multirow{2}{*}{1} & NSA5 & $1: 5$ & 0 & 61 & 0.88 \\
\cline { 2 - 6 } & RCSA5 & $1: 5$ & 0 & 60 & 0.85 \\
\hline 2 & NSA7 & $1: 7$ & 0.35 & 64 & 0.87 \\
\cline { 2 - 6 } & RCSA7 & $1: 7$ & 0.35 & 62 & 0.86 \\
\hline \multirow{2}{*}{3} & NGA5 & $1: 5$ & 0 & 63 & 0.89 \\
\cline { 2 - 6 } & RCGA5 & $1: 5$ & 0 & 61 & 0.87 \\
\hline \multirow{2}{*}{4} & NGA7 & $1: 7$ & 0.35 & 65 & 0.90 \\
\cline { 2 - 6 } & RCGA7 & $1: 7$ & 0.35 & 64 & 0.88 \\
\hline
\end{tabular}

Table 8. Fresh density and oven dry density of all no fine concrete mixes.

\begin{tabular}{|c|l|c|c|c|}
\hline $\begin{array}{c}\text { Set } \\
\text { No. }\end{array}$ & Mix & $\begin{array}{c}\text { Fresh } \\
\text { density } \\
\mathrm{kg} / \mathrm{m}^{3}\end{array}$ & $\begin{array}{c}\text { Oven dry } \\
\text { density at } \\
1 \text { days } \\
\mathrm{kg} / \mathrm{m}^{3}\end{array}$ & $\begin{array}{c}\text { Oven dry } \\
\text { Density } \\
\text { at 28days } \\
\mathrm{kg} / \mathrm{m}^{3}\end{array}$ \\
\hline \multirow{2}{*}{1} & NSA5 & 1850 & 1740 & 1790 \\
\cline { 2 - 5 } & RCSA5 & 1735 & 1650 & 1705 \\
\hline 2 & NSA7 & 1780 & 1685 & 1730 \\
\cline { 2 - 5 } & RCSA7 & 1680 & 1610 & 1660 \\
\hline \multirow{2}{*}{3} & NGA5 & 1950 & 1800 & 1860 \\
\cline { 2 - 5 } & RCGA5 & 1800 & 1710 & 1768 \\
\hline \multirow{2}{*}{4} & NGA7 & 1835 & 1720 & 1775 \\
\cline { 2 - 5 } & RCGA7 & 1735 & 1680 & 1710 \\
\hline
\end{tabular}

Table 9. Average compressive strength result for no fine concrete mixes.

\begin{tabular}{|l|l|l|l|l|l|}
\hline \multirow{2}{*}{$\begin{array}{l}\text { Set } \\
\text { No. }\end{array}$} & Mix & \multicolumn{4}{|c|}{ Compressive strength MPa } \\
\cline { 3 - 6 } & & 7 days & 28 days & 90 days & 180 days \\
\hline \multirow{2}{*}{1} & NSA5 & 6.80 & 8.10 & 9.82 & 13.40 \\
\cline { 2 - 6 } & RCSA5 & 4.80 & 5.70 & 7.10 & 9.70 \\
\hline \multirow{2}{*}{2} & NSA7 & 6.65 & 7.85 & 9.20 & 13.00 \\
\cline { 2 - 6 } & RCSA7 & 4.55 & 5.50 & 6.60 & 9.40 \\
\hline \multirow{3}{*}{3} & NGA5 & 7.30 & 8.70 & 11.10 & 14.00 \\
\cline { 2 - 6 } & RCGA5 & 5.10 & 6.30 & 8.10 & 10.40 \\
\cline { 2 - 6 } & RCGA7 & 4.80 & 6.10 & 7.8 & 9.80 \\
\hline
\end{tabular}

Table 10. The compressive strength for all no fine concrete specimens subjected to 60 cycles of freezing - thawing.

\begin{tabular}{|l|l|c|c|c|}
\hline $\begin{array}{l}\text { Set } \\
\text { No. }\end{array}$ & Mix & \multicolumn{2}{|c|}{ Compressive strength MPa } & $\begin{array}{l}\text { Percentage } \\
\text { of reduction }\end{array}$ \\
\cline { 3 - 5 } & & $\begin{array}{l}\text { No cycle (28 } \\
\text { days) }\end{array}$ & 60 cycles & \\
\hline 1 & NSA5 & 8.10 & 7.6 & 6.2 \\
\cline { 2 - 5 } & RCSA5 & 5.70 & 4.5 & 21.1 \\
\hline 2 & NSA7 & 7.85 & 6.8 & 13.4 \\
\cline { 2 - 5 } & RCSA7 & 5.50 & 4 & 27.3 \\
\hline 3 & NGA5 & 8.70 & 7.92 & 8.9 \\
\hline
\end{tabular}

\begin{tabular}{|l|l|l|l|l|}
\hline & RCGA5 & 6.30 & 4.8 & 23.8 \\
\hline \multirow{2}{*}{4} & NGA7 & 8.60 & 7.5 & 12.8 \\
\cline { 2 - 5 } & RCGA7 & 6.10 & 4.5 & 26.2 \\
\hline
\end{tabular}

Fig. 2-b indicates the effect of gradation type of aggregate (single size and graded) on the freezing thawing for no fine concrete. Using graded size led to increase in the compressive strength for specimens that are subjected to freezing-thawing as compared with using single size of coarse aggregate particles, due to reduction in the volume and number of voids and pores.

\section{$6.5 \mathrm{Immersed}$ in nitric acid [compressive strength of no fine concrete]}

Results for all no fine concrete specimens immersed in Nitric acid $\left(\mathrm{HNO}_{3}\right)$ are presented in Table 11. The results of compressive strength for mixes show slight increase with age due to hydration of cement. Although the results showed a reduction in strength for all specimens at age of $(7,28,90$ and 180) days as compared with specimens cured in water, see Fig. 3. This reduction was due to transformation of $\mathrm{Ca}(\mathrm{OH})_{2}$ to a highly soluble nitrate salt resulting in greater deterioration as shown by equation $\left(2 \mathrm{HNO}_{3}+\mathrm{Ca}(\mathrm{OH})_{2}\right.$ $\left.\rightarrow \mathrm{Ca}\left(\mathrm{NO}_{3}\right)_{2}+2 \mathrm{H}_{2} \mathrm{O}\right)$ (Calcium Nitrate). With the help of water, these soluble salts may easily be transported to the outer parts of cement. In this situation, continuous reactions increase the porosity of cement paste and increased pore volume speed up the rate of reaction. 


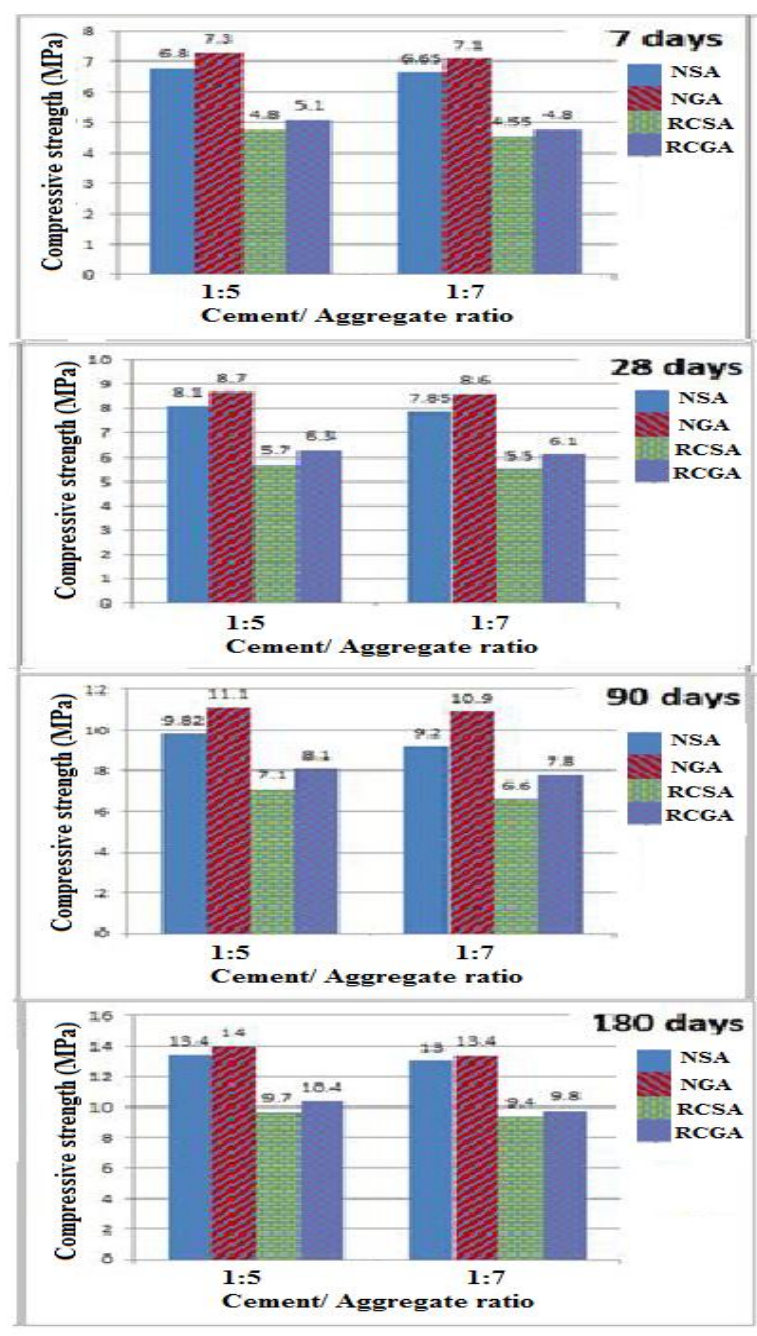

Fig. 1 :Compressive strength and C/A ratio relationships at (7, 28, 90 and 180) days age.

The Ordinary Portland cement is a highly alkaline material ( $\mathrm{pH}$ above 12.5) and thus, as $\mathrm{pH}$ decreases the equilibrium of the cement matrix is disturbed and hydration compounds are easily changed by hydrolytic decomposition. From results of different test ages indicating slightly increased in compressive strength. Results of no fine concrete with demolished concrete as recycled coarse aggregate were lower than natural coarse aggregate in all ages due to the weakness in properties for this type of aggregate. On other hand, rubble concrete aggregate be surrounded by old cement leading to more interaction causing reduction in the hydration rate.

Reduction in compression strength results increased as the percentage of cement ratio/coarse aggregate increased. This is mainly due to the low mortar content and the high porosity. Using graded size aggregate led to increase in compressive strength as compared with using single aggregate size. Due to increase in the bond strength between cement paste and aggregate particles.

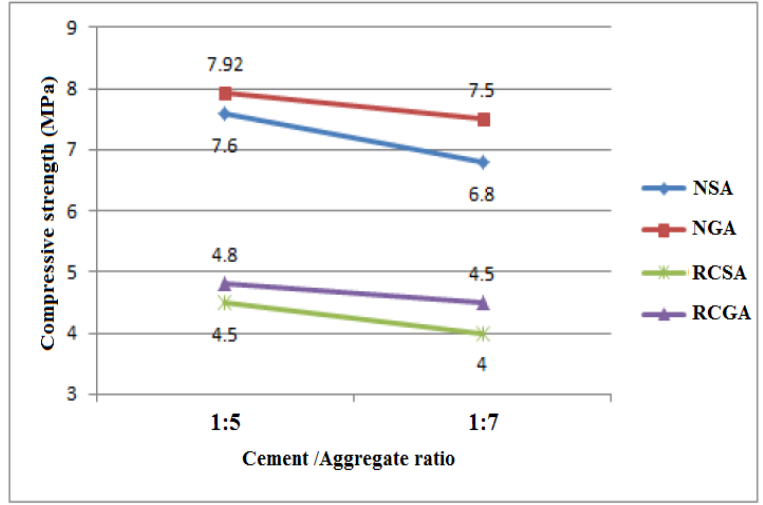

a- Compressive strength and C/Aggregate ratio relation.

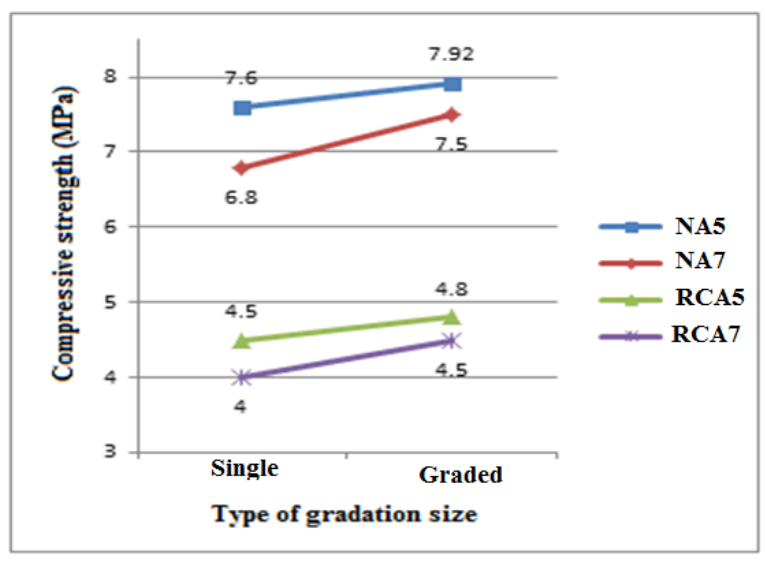

b- Compressive strength and type of gradation.

Fig. 2 Relationship between compressive strength and C/Agg and type of gradation after 60 cycles of freezing - thawing.

Table 11. Compressive strength of all no fine concrete mixes specimens immersed in nitric acid $\left(\mathrm{HNO}_{3}\right)$.

\begin{tabular}{|c|l|l|l|l|l|}
\hline $\begin{array}{c}\text { Set } \\
\text { No. }\end{array}$ & \multirow{2}{*}{$\begin{array}{l}\text { Mix } \\
\text { Designation }\end{array}$} & \multicolumn{4}{|l|}{ Compressive Strength (MPa) } \\
\cline { 3 - 6 } & & 7 days & $\begin{array}{l}28 \\
\text { days }\end{array}$ & $\begin{array}{l}90 \\
\text { days }\end{array}$ & $\begin{array}{l}180 \\
\text { days }\end{array}$ \\
\hline \multirow{2}{*}{1} & NSA5 & 4.1 & 4.6 & 6.3 & Ү.2 \\
\cline { 2 - 6 } & RCSA5 & 2.2 & 2.8 & 4.15 & 5.4 \\
\hline \multirow{2}{*}{2} & NSA7 & 3.9 & 4.15 & 5.1 & 6.6 \\
\cline { 2 - 6 } & RCSA7 & 2 & 2.6 & 3.3 & 3.9 \\
\hline \multirow{2}{*}{3} & NGA5 & 6.1 & 6.8 & 7.5 & ^.1 \\
\cline { 2 - 6 } & RCGA5 & 3.3 & 4 & 5.1 & 5.8 \\
\hline \multirow{2}{*}{4} & NGA7 & 4.4 & 6.2 & 6.9 & 7.3 \\
\cline { 2 - 6 } & RCGA7 & 3 & 3.85 & 4.4 & 5.2 \\
\hline
\end{tabular}




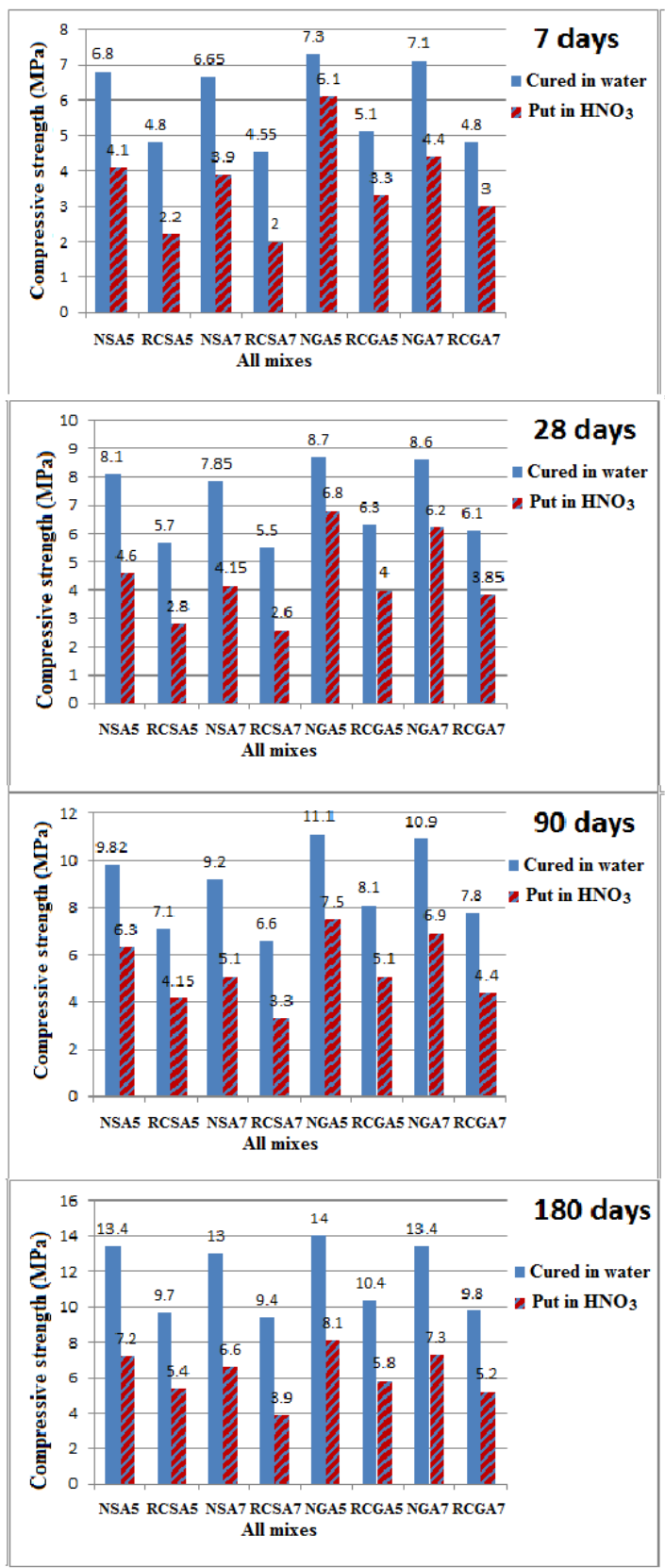

Fig. 3 The change in the compressive strength for specimens cured in water and these kept in acid solution (HNO3) for all ages.

\section{Conclusions}

Based on the results of this research, the following conclusions may be drawn:

1- The workability of no fine concrete produced by demolished concrete as coarse aggregate is less than the workability of no fine produced by natural crushed aggregate. The flow test and compaction factor of no fine concrete produced with $\mathrm{C} / \mathrm{A}$ ratio of 1:5 was less than no fine concrete produced with 1:7. The results of flow test and compaction factor of nofine concrete produced with single aggregate type is less than that of no-fine concrete produced by graded aggregate by about $2 \%$.
2- The hardened properties compressive strength and oven dry density for no-fine concrete produced by demolished concrete as coarse aggregate were less than that of no-fine produced by natural crushed aggregate. The hardened properties for no-fine concrete produced with C/A 1:5 were higher than no fine concrete produced with $\mathrm{C} / \mathrm{A}$ 1:7. The harden properties for no fine concrete produced by single aggregate size was less than no fine produced by graded aggregate.

3- Using graded aggregate produce higher compressive results for all tests than specimens with single graded aggregate this was due to less voids in the mix.

4- Results for both freezing-thawing cycles and immersing in nitric acids indicated that the compressive strength increases with decreasing the percentage of cement ratio /coarse aggregate. This is mainly due to the high mortar content and the low porosity.

5- The compressive strength for specimens immersed in acidulous solution $\left(\mathrm{HNO}_{3}\right)$ shows a slight increase with age up to 180 days. No fine concrete produced with 1:5 C/A ratio exhibits higher compressive strength, than that of no fine concrete with 1:7 C/A ratio by about (5-38.7) \%.

\section{References}

1. A. M.Neville A. M., "Properties of Concrete", fifth Edition, First published 2010.

2. Abadjieva \& Sephiri ,Dept. of Civil Eng., University of Botswana, Private Bag 0061, Gaborone, Botswana,pp.1-6.

3. H. Wen, I. D. McLean and K. Willoughby, 2015 TRB Annual Meeting and Publication in the Transportation Research Record: J. T. R. B.

4. B. Witchayangkoon, M. Pattanasuwan, P. Nakarin and P. Jampatong. P, ATEAS, http://TuEngr.com/ATEAS.

5. H. Qasrawi, I. Marie and H. Tantawi. Conference: Proceedings of the 5th Jordanian International Civil Engineering Conference, At Amman, Jordan, January 2012, pp.1-7.

6. IQS. No.5-1984, "Portland cement", Iraqi Standard Organization, COSQC.

7. IQS. No. 45-1980, Iraqi Standard Organization, COSQC.

8. ASTM C494-04, Annual Book of ASTM Standards, ASTM, Vol. 04-02, pp. 1-8, 2004.

9. ASTM C124-76, Annual Book of ASTM Standards, ASTM, Vol. 04-02, pp. 1-8, 2004.

10. BS 1881: Part 103: 1993, British Standards Institution, 1881; pp. 3. 
11. ASTM C138-01, Annual Book of ASTM Standards, pp. 4, 2001.

12. BS 1881: Part 116: 1989, British Standards Institution, 1881; pp. 3.

13. ASTM C666-03, Annual Book of ASTM Standards, ASTM, Vol. 04-02, pp. 1-8, 2004.

14. K. Josiphiah, D. Yusuf. And T. Kassar.T, Civil and Environmental Research, ISSN 2224-5790 (Paper) ISSN 2225-0514 (Online), Vol.7, No.12, 2015. 